\title{
Are We Clear, Now? : Analysis of the Effectiveness and Legitimacy of Bill C-20, the Clarity Act (2000)
}

\section{Natalie Bradbury}

\section{Dalhousie University}

\section{Abstract:}

The purpose of this paper is to analyze the effectiveness and legitimacy of the Clarity Act (2000) within the context of federal-provincial relations. Effectiveness is gauged by the extent to which the Act achieves its initial goals of clarifying government's position on separatism, redefining terms (such as 'majority') and diminishing support within Quebec for sovereignty. Legitimacy is assessed through examining whether or not the federal government has the legal ability to make decisions on the type of majority/question that a province needs for sovereignty. There are several arguments that maintain that this should remain within the jurisdiction of the provincial legislature. The historical events that led up to the Act are discussed as evidence of the Act's reflection of continuities that plagued Quebec-Canada relations. While analyzing expert opinion, the author brings together both pro- and anti- Clarity Act perspectives in order to arrive at her conclusion. Revisiting statistical work by Pinal is used to gauge the Quebecois reaction to the Act. The author concludes, ultimately, that the Clarity Act is both an effective and legitimate response to calls for Québec sovereignty. The Act upholds democratic values and supports national unity. The controversy surrounding the Act accentuates the value of debate within the intergovernmental political realm. 
Any prime minister faced with the very real threat that the country could break up before his/her very eyes must carefully consider, in advance, the best available options before the unthinkable actually occurs. Prime Minister Jean Chrétien was once put squarely in the position of facing the break up of Canada. So shaken afterwards, he vowed that in any 'next time' his, or any future Canadian government, would have already taken measures aimed at staving off a rupture in the federal fabric and have the best chance to succeed in keeping Canada in one piece.

In an attempt to pacify the separatist movement that flourished in Québec from the 1960s to 1990s, the Canadian government developed the Clarity Act of 2000. This paper will present the events that led up to Clarity Act's implementation as well as evaluate its effectiveness and legitimacy. While there are some nuances in regards to how the Act was received across the political sphere, it is possible to conclude that it was both an effective and legitimate response to calls for Québec sovereignty. Its overall effectiveness is reinforced as it achieved its initial goals of redefining central terms, clarified the government's position and reduced the support for the sovereignty movement. In a parallel evaluation, its legitimacy was secured because the federal government is entitled to make decisions on the type of majority/question that a province presents although there are solid arguments that suggest this should remain within the jurisdiction of the provincial legislature. Finally, any breach(es) in the legislation's effectiveness will consequently be considered a loss of legitimacy. Ultimately, the Clarity Act had a profound impact on Québec-Canada relations as well as acting as an example of the intergovernmental debates and values that are embedded in contemporary Canadian politics.

The Quiet Revolution of the 1960s changed the focus of Quebec nationalism from cultural independence through defending traditional values to politically charged and oriented towards autonomy. An example of this political mobilization of nationalism is certainly the creation of the separatist party, the Parti Québeçois, in 1968. Québec's innovative leaders, such as René Lévesque and Jean Lesage, pursued a more aggressive and modern form of nationalism which has since then became a key issue of contention in Québec politics and policy making. The importance of this new nationalism increasingly pointed to one question: "How much decentralization should govern relations between Québec and Canada?”(1)

The intergovernmental debate between the Government of Canada and the Government of Quebec is, undoubtedly, a continuity of historic tensions. From the 1960s to the 1980s, there were two lingering and unresolved issues that would affect decision-making across federal-provincial relations: National unity and the negative repercussions provinces experienced due to a decline in federal transfers. Furthermore, Québec had usually been a consistent force of resentment and disobedience to national projects as the province's political culture defines itself as a distinct society that is unique from the Rest of Canada (ROC). These bitter feelings were heightened by the fundamental "constitutional dissatisfactions and economic concerns" that had existed for many decades.(2) By the 
end of the 1980s, the mounting inevitability of Québec secession was growing at a steady pace.

The Mulroney government in the 1980s exercised constitutional federalism through political compromises and settlements as well as institutional changes. Unfortunately, the attempts he (and his successors) pursued fell short. The tensions in Québec increased as a result of the failure of national projects, particularly the Meech Lake and Charlottetown Accords that attempted in vain to bring Québec back into the Canadian Constitution. When these accords died, Québec felt rejected and took this as the ROC's way of "further excluding [it, which] led to a rise for sovereignty support.”(3) With Mulroney's retirement and Kim Campbell's short executive stint, Jean Chrétien became Prime Minister with a huge majority in 1993 and brought with him a commitment to ensuring Québec's place in Canada. Ultimately, Québec would remain at the front of the political battlefield. Three main events forced the government to pay serious attention to the province's nationalism as a potentially dangerous issue:

The 12 September 1994 election of a Parti Québeçois government committed to independence with 75 seats versus the Liberals' 48 seats and 1 seat to the Parti Action Démocratique;

The formal launching of the sovereignty referendum process with the 6 December 1994 tabling of legislation in the National Assembly; and

The extremely narrow federalist win, at $50.6 \%$ of the vote, when the referendum was eventually held on 30 October 1995. (4)

The federal government needed to respond and strengthen the country because it looked as if it was going to disintegrate. There was considerable panic in the ROC and Chrétien's credibility was on the line. To add even more pressure on Ottawa, the Québec government was "establishing a process that would include consultations with the Quebecers (prior to, and in the form of, a referendum) and the National Assembly (prior to, and in the event of, a "yes" vote after a referendum.)"(5) In response, the government produced several programs that formed what is known as "Plan A" and "Plan B." These projects emerged mostly in 1996 as a means to popularize national unity while attempting to solve some of Québec's constitutional concerns without changing the Canadian Constitution itself. Plan A projects are soft-line approaches that seek to appease Québec. These initiatives consisted of: Bill C-110, a resolution to recognize Québec as a distinct society, talks of opting-out of new shared-cost programs and devolving labour force training to the provinces.(6) The Calgary Declaration was another national unity project but it was rejected by Bouchard's government. The initiative was unattractive to the province's government because it only recognized Québec's society as a unique part of the greater Canadian entity rather than acknowledging the province as a nation which has political implications. 
The Plan A initiatives were followed by two main Plan B projects: The Québec Secession Reference to the Supreme Court of Canada and the Clarity Act. To qualify, Plan B refers to the government's preparation in the eventuality that a referendum yields a "yes" response and more specifically, it involved "hardening their position towards Québec.”(7) Chrétien was (justifiably) scared by the near breakdown of the country. He referred to the Supreme Court three questions in late 1996 which asked the Court to determine the extent of power that the Québec government legally possessed (by the standards of national and international law) to unilaterally secede from Canada. As a follow up question based on the result of the first two, the Court had to decide which body of law took precedence if the laws conflicted. In the end, the Reference "aimed not only to declare the unconstitutionality under Canadian law, but the invalidity, under international law, of any Québec law that would propose a referendum on the sovereignty of Québec."(8) It is important to note that the Court provided an opinion of the requirements for clarity, not a decision, which meant that it was not legally binding.

The 1998 Supreme Court Reference concluded several main points. Firstly it determined that Québec could not secede unilaterally under either Canadian or international law. Secondly, the Supreme Court qualified the referendum issue by saying if a democratic will to secede existed on a clear question and clear majority, the ROC was obligated by law to negotiate with that seceding province. Thirdly, it would be up to the federal government to decide what constituted a "clear" question and majority. Such a vital decision as secession was advised to have an "enhanced majority" since the standard of "fifty percent plus one” of the population's support was simply not sufficient.(9) Finally, the Court interpreted secession as a constitutional change and thus the terms of secession would be "subject to the conditions of the democratic principle" guaranteed by the document.(10)

The Supreme Court offered advice that was both cautious and calculated. The opinion purposefully left the clarity of the question up to the federal government because the Supreme Court felt the decision went beyond their ability and it also recognized that perhaps the best decision makers here should have been the Quebec people themselves. Additionally, the Supreme Court was able to appease both the federal and Québec governments. The Court essentially granted both Ottawa and the Québec government legal authority to develop a coherent decision. Ultimately, the Court provided a "win" for both sides. The central government could use the opinion towards a national unity project and the Québec sovereigntists were happy as the ROC was forced to negotiate if the conditions of clarity were met.

Following the 1998 Supreme Court Reference, Bill C-20 emerged as the follow-up Plan $\mathrm{B}$ initiative produced by the federal government. The bill, which became the Clarity Act, both echoes and elaborates on the Supreme Court's opinion. Essentially, the Clarity Act details the conditions and methods that are required for the secession of any province to be recognized by the Canadian government. It is the Parliament of Canada that will judge the clarity of the referendum question addressing sovereignty and the majority "required to conclude that the consulted population is in favour of the idea" before the 
public votes on that referendum.(11) In addition, Parliament reserves the right to evaluate the following conditions when judging if a clear majority has been attained: "the size of the majority of valid votes cast in favour of the secessionist option; the percentage of eligible voters voting in the referendum; and any other matters or circumstances it considers relevant.”(12) Finally, the legislation sets out a framework Parliament must work within when deciding on the clarity of the question.

The Clarity Act stipulates what is to occur in the event that a separatist referendum in Québec was successful. In this case, the members of the Canadian federation as well as the First Nations would "have an obligation to engage the Québec government in goodfaith negotiations to put into effect the clearly expressed will of Quebecers" to separate.(13) The concept that secession would required a constitutional amendment as the Supreme Court established in the 1998 Reference, was echoed in the Clarity Act as such a huge event as secession would absolutely require consensus among all ten provinces. This is conditional since the referendum question posed to the people must only relate to secession: any post-secession reference negates the option of negotiations with Parliament. It is also imperative to add that the Act concluded that any referendum that violated the conditions set fourth in the legislation would be discredited by Parliament. For example, if Parliament deems the question unclear, the referendum and its results will be discounted and negotiations will not occur.

The federal government had several goals (both latent and manifest) that it sought to achieve through the Clarity Act. The main idea was to prevent a future referendum on secession in order to maintain national unity through a "legislative intervention."(14) Moreover, the government of Canada had "a moral obligation to ensure that [democratic and nationalistic] values [were] respected, regardless of the short-term effect on nationalist sentiment in Québec.”(15) This was to be achieved by clarifying the terms that are crucial to a result that has the potential to literally divide the country. Furthermore, from the outset of the preamble, the goal is not to limit the province's right to "hold referendums or determine the question itself" because the government cannot legally do this as it is a clear violation of the Constitution and Charter of Rights and Freedoms.(16) What the government can do through constitutional means is place conditions on whether a question and majority are clear enough in order to proceed with secession negotiations.(17) Stéphane Dion echoed the same kind of moral rhetoric in stating that "the Act protects the rights and interests of all Canadians from undemocratic attacks on federalism."(18) Finally, another goal was to create a "concrete form" of the Secession Reference, which was based on upholding the "lifeblood principles of the Constitution: federalism, democracy and the rule of law.”(19)

There are more subtle goals that the government hoped to achieve. Optimists suggest that the Clarity Act's understated goals were to prevent governments from using confusing language to mold the behaviour of voters. Critics suggested the referendum question was a deliberate trick played by Jacques Parizeau's National Assembly to manipulate Quebecers into voting for separation without presenting the explicit words. Data from a poll conducted by sociologist Maurice Pinard clearly indicates that Quebecers did not 
understand the question.(20) There is certainly good reason to find it confusing. Examining the passage reveals that the question is actually asking Quebecers to say yes to four very different items in only forty eight words.(21) The Clarity Act would thus act as a bulwark against any separatist regimes that attempted to divide Canada through deception. The Clarity Act benefits all Canadians since the government now has a plan in the event of another referendum that attempts to mislead people against their democratic right to understand what they are voting for. Claude Ryan challenges this as he explains it would be political suicide as "a sovereigntist government that pursued ambivalent strategies would [in fact] lessen its chances of a successful negotiation.”(22)

Optimists go on to suggest that the Clarity Act has two other subtle goals: Qualifying items the Reference did not and determining a federal government plan for both internal pressure and legitimacy reasons. Monahan argues that it was necessary on the government's part to create legislation before another referendum was called in order to clarify the "uncertainties" that were left by the Supreme Court's declaration.(23) As an example, he cites that because the Court did not define the majority required to trigger negotiations, there was immediate pressure on the government to determine what the standard should be. In a parallel line of thought, Ryan suggests that it was crucial for the government to "take action now [as] the alternative would be to wait until another sovereignty referendum was imminent [which] at that point, the risks of such an initiative [as the Clarity Act] would have increased dramatically.”(24) Legitimacy is enhanced with an Act as it would be ratified by the legislative process instead of the government simply producing a "white paper outline [...] in the crunch of a real referendum.”(25)

Pessimists believe quite the contrary. They suggest the legislation is meant to calm the ROC (not help Quebec), reflect intimidation tactics and demonstrate Parliament's ultimate power. Lajoie believes the Act is an "ideological effect" to pacify the panicstricken ROC by suggesting the legislation would keep Québec in Canada by "discouraging it from organizing a referendum and asking a question of its choice [as well as convincing the ROC] that any question that would not meet the requirements of the Clarity Act [...] would be illegal and unconstitutional.”(26) Critics suggest that the government may have been trying to put down the view in the ROC that the Québec sovereignty movement had an increasingly unilateral approach (Rocher and Verrelli 219). By specifically looking at the Clarity Act from the point of view of minority rights, Rocher and Verrelli suggest the Act's goals can bee seen as a "bullying tactic by the feds to intimidate Quebecers [and] side step its duty to negotiate.”(27) They go on to describe that the government's aim is "primarily to reassert before Québec and the ROC Parliament's legitimacy when intervening in the referendum process, before the National Assembly has the opportunity to hold a referendum and, for that matter, even before it adopts the wording of the referendum question."(28) These scholarly reasons and retorts impact the ideologies in the National Assembly today as there is consensus amongst its parties that agree the Clarity Act is only worth ignoring.(29)

One of the most controversial aspects of the Québec secession movement is the vague nature of "sovereignty" which means different things to different people. Typically in 
Québec, "economic and political ties were always linked to the sovereigntist movement, although in different forms."(30) Parizeau never outright said separation, but did a lot of talking about Québec becoming a sovereign country only after a formal offer was made to Canada for both economic and political partnership(31). When Bouchard took over from Parizeau, the support of the "yes" side took off and the federal government and the "no" committee were almost too late in realizing Bouchard's impact and respect in Quebec.

The Clarity Act can be seen as an urgent remedy to the growing sovereigntist movement which is stifled by the federal government bursting their sovereigntist bubble about what Quebecers thought they would be getting. The Clarity Act echoes Dion's 1990s “writing campaign where he wrote a series of letters attacking the common wisdom on sovereignty."(32) The legislation was as much an effort by the central government to have a fighting chance to persuade Quebecers against any future separation referendums and at least to qualify that a "yes" vote means full separation: No passport, no pension, no territory and absolutely no sovereignty-association. The act is quick to specify what separation is in Section 1, where it states that the legislation is dealing with the issue of "whether [a] province should cease to be part of Canada." [emphasis added]

Politically, the Act consolidated Chrétien as he was able to diffuse a volatile political situation. In addition, the Act did reduce the support for the sovereignty movement. Chrétien came out a winner in the ROC and, in reality, lost nothing in Québec because he was not always unpopular there. When the initial referendum question went public, Chrétien kept quiet while other ministers and premiers fought it out for federalism over separatism. His passage of the Act helped soothe his place in history too, given that he almost lost the country by inactivity and not taking the upcoming referendum more seriously until it was almost too late. In addition, it was politically smart to have Dion (as the Intergovernmental Affairs Minister) write the bill as he was a native Québecer. This, of course, is debatable as he did also receive very negative reaction in Québec for his role. In terms of reducing support for the sovereignty movement, the "early poll results following the introduction of the Clarity Act indicates that a majority of Quebecers disapprove of the legislation, [although] they [do show] a decrease in support for sovereignty."(33) The support has since fluctuated, suggesting that the sovereignty movement is a dynamic one that shifts depending on the political personnel and developments of the time.

It is also possible to evaluate legitimacy based on the gaps in the Act's effectiveness. There are certainly some holes in the fabric of this legislation that result in a loss of legitimacy such as the condition of excluding any post-secession references and lack of clarity as to what constitutes a majority. The Clarity Act lacks democratic weight as it "goes beyond the Supreme Court's decision" because it states the government will ignore any referendum question that "includes a reference to post-secession economic or political arrangements with Canada."(34) This is a hole that can be filled if the legislation was amended to include the post-secession wording since this extension does not necessarily muddle the clarity of the question.(35) In a parallel vein, the refusal to 
negotiate because the question includes this post-secession extension brings Ryan to basically equate the Act as a Parliamentarian ultimatum.(36)

Finally, the Act does not have a mechanism or formula in place in order to judge whether a strong enough majority has been reached. This ambiguity is certainly a gap. On the other hand, some scholars suggest that if a threshold was settled, this would be politically binding for the government and would have the potential to backfire. Both Ryan and Monahan agree that this should be specified: The former suggesting a majority of the eligible voters as threshold which has "political plausibility in Québec political circles"(37) and the latter believing that the government should "provide a threshold before the referendum takes place to promote accountability and transparency [as opposed to] the alternative reflected in Section 2.”(38)

There are some gaps that have no solutions and thus the Clarity Act can be seen as partially flawed. These gaps are that it is unjust that Parliament is pursing a unilateral judgment on clarity and that the legislation does not define what the "other circumstances" in section 1(5) are. Firstly, Lajoie indicates that there is a fundamental problem with the Act which is "the fact that the Canadian government, or, more specifically, the governing party, becomes the sole judge of what constitutes a "clear" question and a "clear" majority."(39) She believes that the lack of input from the National Assembly and debate within Québec is ultimately unfair. This is ironic as the central government seems to be pursuing the very same unilateral strategy that it was trying to dismiss in the National Assembly. Secondly, the other circumstances that the state will examine when judging the clarity of the question are never defined. This creates a degree of open-endedness that is not settled by the legislation. Ultimately, the Act's legitimacy is blurred as it is only Parliament that decides what the "other views to be considered” actually are.

There are two main schools of thought - the pessimists and the optimists - that are engaged in a debate about whether the Clarity Act ultimately infringes on Québec's jurisdiction. The pessimists mainly see the Clarity Act as an "intervention in the referendum process at a stage when, by its own admission, this process lies within the jurisdiction of the Québec National Assembly.”(40) Critics' main argument is that the Québec people (as a cultural minority in Canada) are being subordinated by Parliament as they are no longer in control of either the question or the majority that are required for their referendum to be legitimate. The Clarity Act, to pessimists, is stripping Québec from its right to "redefine its political future" through its own means and definitions “without external interference.”(41) Finally, the Clarity Act is seen by some as "political propaganda [which] sells the idea that the Clarity Act enables the National Assembly to pose any question it wants at the time of a referendum however it also enables them to add that [its credibility is completely subject to Parliament’s approval.]”(42)

It is important to note that these arguments have a decree of political weight as they have been echoed in the Québec legislature. These pessimistic views were materialized into 
legislation (Bill 99) by the Québec government even though the passage of Bill C-20 did not foster any substantial protest within Québec. Bill 99 contradicted the Supreme Court Reference stating that it does not apply in Québec, the "fifty percent plus one" formula was still valid and that only the Québec government could pursue self-determination. Although the legislation went mostly unnoticed, it proved that the Québec government was not done with the sovereignty question.

The idea that Parliament is intruding in provincial jurisdiction is challenged by the optimists that see the legislation as legitimate and necessary. They believe this because it does not infringe on Quebec's jurisdiction, it follows the constitution's principles and it prevents unilateralism. The Act's main goal is to "indicate the criteria to which federal parliamentarians should refer in the case of a referendum on the secession of a province and to judge both the clarity of the question and the adequacy of the majority."(43) This does not at all refer to removing legislative power from the Québec National Assembly. It is, in fact, in line with section 44 of the Constitution Act (1982) which allows the federal government to "unilaterally amend the constitution on issues that are strictly within the federal jurisdiction.”(44)

The Act follows constitutional principles and avoids unilateralism. The Clarity Act reinforces the Peace, Order and Good Government clause "both in respect of entering negotiations for secession and in respect of proposing a constitutional amendment.”(45) Furthermore, the Clarity Act maintains democratic values because not only did it follow the opinion of the Supreme Court, but the clarity of the question and majority will be judged by an elected body (Parliament) and the negotiations will be multilateral, not unilateral. Therefore, the Act is legitimate since the federal government is entitled to "indirectly influence [the Québec National Assembly's] members and their electorate."(46) The Clarity Act prevents the alternative, which is the province unilaterally dictating the conditions of secession to the central government, since legislation is binding to all provinces in Canada.

In acknowledging the contradicting opinions on the effectiveness and legitimacy of the Clarity Act, it is possible to see the legislation in two distinct lights. The legislation is both a beneficial safeguard "designed to promote democratic accountability and protection against arbitrary action by government"(47) as well as the federal government's way to keep Canada intact by "ensure that Québec would never meet all the conditions needed to legally secede from Canada.”(48) The Clarity Act is effective in promoting national unity as well as most of the principles outlined in the Supreme Court Reference. In terms of its legitimacy, most literature agrees that the Clarity Act has done more good than damage in upholding the democratic values embedded in Canadian political culture. The controversy and dialogue surrounding the Clarity Act and the sovereigntist movement are certainly important features of Canadian politics. In fact, the very reality that debates exist in any political realm is an implication that democracy is in practice.(49) It is within the context of these political debates that the values and principles of Canada's Charter of Rights and Freedoms are able to emerge. 


\section{Biography}

Natalie Bradbury is a student at Dalhousie University in Halifax, Nova Scotia, completing a double-major in History and Political Science. Originally from Ottawa, Ontario, she attributes her early interest in these disciplines to her own family's diverse history and the inspirational education she received in school. Natalie was inspired by Dalhousie professor Dr. Kristin Good who has assisted Natalie in cultivating and advancing her appreciation for and understanding of the dynamics of Canadian federalism. Natalie's other interests include experiencing first hand other jurisdictions and cultures that she has obtained through extensive international travel. Natalie is considering a career in academia and is particularly interested in specializing in federalism and contemporary history. This summer, she looks forward to her job as an assistant research analyst with the federal government. 
Federalism-e: Volume 9

Footnotes

(1) Meadwell 203.

(2) Mollie Dunsmuir, Background to the introduction of Bill C-20, the Clarity Bill, Parliamentary Research Branch (2000): 6, 22 Nov. 2007 http://dsppsd.pwgsc.gc.ca.ezproxy.library.dal.ca/dsp-psd/Pilot/LoPBdP/BP/prb9942-e.html

(3) Jack Stilborn and Robert B. Asselin, Federal-Provincial Relations, Library of Parliament (2001) 22 Nov. 2007 http://dsp-psd.pwgsc.gc.ca

(4) Stilborn and Asselin.

(5) Stilborn and Asselin.

(6) Dunsmuir 8.

(7) Andrée Lajoie, The Clarity Act in its Context, Québec: State and Society (third edition), ed. Alain-G. Gagnon (Peterborough, ON: Broadview Press, 2004) 152.

(8) Lajoie 153.

(9) Rocher and Verrelli 231.

(10) Patrick Monahan, Doing the rules: An assessment of the federal Clarity Act in light of the Québec Secession Reference, C.D. Howe Institute (2000): 159, 22 Nov. 2007 http://www.cdhowe.org/display.cfm?page=research-governance\&year=2000

(11) Lajoie 151.

(12) Rocher and Verrelli 217.

(13) Ryan 21.

(14) Lajoie 161.

(15) Ryan 36.

(16) Monahan 29.

(17) Monahan 29.

(18) Rocher and Verrelli 227.

(19) Rocher and Verrelli 209. 
(20) Lajoie 152.

(21) Ryan 8.

(22) Ryan 19.

(23) Monahan 29.

(24) Ryan 36.

(25) Ryan 19.

(26) Lajoie 161.

(27) Rocher and Verrelli 224.

(28) Rocher and Verrelli 218.

(29) F. Abbas Rana, The Spin Doctors: Parti Québecois Leader Andre Boisclair says he will not respect the Clarity Act. Should this be an issue in the upcoming election and why?, The Hill Times on the Web 28 Nov. 2005, 22 Nov. 2007: 17. http://www.thehilltimes.ca/

(30) Rana 17

(31) Abbas 17

(32) Alexander Panetta, Dion again writes letters to tackle common views in Québec this time on himself, Canadian Press News Wire, Toronto (2007): 77. http://proquest.umi.com.ezproxy.library.dal.ca

(33) Monahan 4.

(34) Monahan 30.

(35) Monahan 30.

(36) Ryan 27.

(37) Ryan 27.

(38) Monahan 31.

(39) Lajoie 216. 
Federalism-e: Volume 9

(40) Rocher and Verrelli 229.

(41) Rocher and Verrelli 220.

(42) Rocher and Verrelli 216.

(43) Lajoie 161.

(44) Rocher and Verrelli 229.

(45) Rocher and Verrelli 229.

(46) Lajoie 161.

(47) Ryan 36.

(48) Rocher and Verrelli 220.

(49) Rocher and Verrelli 232. 


\section{References}

1. Dunsmir, Mollie. "Background to the introduction of Bill C-20, the Clarity Bill," Parliamentary Research Branch (2000): 6, 22 Nov. 2007 http://dsppsd.pwgsc.gc.ca.

2. Lajoie, Andrée. “The Clarity Act in its Context,” Québec: State and Society (third edition), ed. Alain-G. Gagnon (Peterborough, ON: Broadview Press, 2004).

3. Meadwell, Hudson. "The Politics of Nationalism in Québec," World Politics 45 (1993).

4. Monahan, Patrick. "Doing the rules: An assessment of the federal Clarity Act in light of the Québec Secession Reference,” C.D. Howe Institute, Toronto (2000): 159, 22 Nov. 2007 http://www.cdhowe.org/display.cfm?page=researchgovernance\&year $=2000$

5. Panetta, Alexander. "Dion again writes letters to tackle common views in Québec - this time on himself,” Canadian Press News Wire, Toronto (2007). http://proquest.com

6. Rana, F. Abbas. “The Spin Doctors: Parti Québecois Leader Andre Boisclair says he will not respect the Clarity Act. Should this be an issue in the upcoming election and why?,” The Hill Times on the Web 28 Nov. 2005, 22 Nov. 2007. http://www.thehilltimes.ca

7. Rocher, Francois and Nadia Verrelli. “Questioning Constitutional Democracy in Canada: From the Canadian Supreme Court reference on Québec secession to the Clarity Act," The Conditions of Diversity in Multinational Democracies, ed. Alain-G Gagnon, Montserrat Guibernau and Francois Rocher (Montreal, QC: Institute for Research on Public Policy, 2003).

8. Ryan, Claude. "Consequences of the Québec Secession Reference: The Clarity Bill and beyond,” C.D. Howe Institute (2000): 23, 22 Nov. 2007 http://www.cdhowe.org

9. Stilborn, Jack and Robert B. Asselin. “Federal-Provincial Relations,” Library of Parliament (2001) 22 Nov. 2007 http://dsp-psd.pwgsc.gc.ca 